\title{
KINETICS AND THERMODYNAMICS OF THE SOLID-LIQUID EXTRACTION PROCESS OF TOTAL POLYPHENOLS FROM BARLEY
}

Dušan Đ. Paunović*, Snežana S. Mitić, Danijela A. Kostić, Milan N. Mitić, Branka T. Stojanović, Jovana Lj. Pavlović

(ORIGINAL SCIENTIFIC PAPER) UDC 66.061.34:633.16:547.56

Department of Chemistry, Faculty of Sciences and Mathematics, University of Nis, Nis, Serbia

The influence of the solvent concentration, $\mathrm{pH}$, temperature, sampler solid ratio and extraction time on the extractability of total phenolic compounds from barley was investigated. The most effective solvent $(30 \%$ aqueous ethanol solution with $5 \% \mathrm{HCl} / \mathrm{v}$ ) was used for modeling the solid-liquid extraction of total polyphenolic compounds at the solid-liquid ratio of $30 \mathrm{~mL} / \mathrm{g}$ (the ratio of the solvent volume per gram of raw material). Total phenolic compounds in the barley extracts were determined spectrophotometrically using Folin-Ciocalteu method at $760 \mathrm{~nm}$. The content of the phenolic compounds of extracts depends on the extraction conditions applied. The mechanism of the extraction is confirmed to occur in the following steps: first, the dissolution of the phenolic compounds near the particle surface (washing) and second, the diffusion from the solid particles to the bulk of the liquid extract (slow extraction). The process is described mathematically using two concepts of unsteady diffusion through the plant material and Ponomaryov's empirical equations. The data obtained are used to establish the kinetics and thermodynamics of the extraction process.

\section{Introduction}

Beer flavor stability has become one of the most important topics in brewing science over the past decades [1]. The flavor stability of beer primarily depends on the oxygen contents of packaged beer. Phenolic compounds are antioxidants of beer. Beer is known to contain a wide variety of phenolic compounds, most of which originate from the raw materials of brewing, that is, barley malt and hop. About $80 \%$ of phenolic compounds in beer originate from barley malt and the remaining $20 \%$ come from hops [2]. These phenolic compounds in barley include phenolic acids (benzoic and cinnamic acid derivatives), flavonoids, proanthocyanidins, tannins and amino phenolic compounds $[3,4]$ all of which are known to possess antioxidant and antiradical properties.

Phenolic compounds present in barley extracts are complex and their activities depend on the composition and conditions of the test system. The extraction is a very important stage in the isolation as well as the identification of phenolic compounds. Consequently, many authors have studied the influence of different extraction conditions [5-7] on the extraction yields of phenolic compounds from natural sources. However, there is still no available standardized procedure for a simultaneous extraction of all phenolics. Therefore, there is a need for systematic research related to the determination of food phenolics [8]. A well-known concept of developing, designing and optimizing extraction processes involves several steps. The selection of the proper extraction solvent, plant material comminution degree, plant material- to solvent ratio (hydromodul), temperature and agitation intensity are usually the first important step aiming at the optimum operating conditions of the extraction from a particular plant material. Therefore, there is a need for mathematical modeling of this process. Mathematical models are useful engineering tools which greatly facilitate the simulation, optimization, design and control of processes and contribute to the utilization of energy, solvent and time [9]. For this reason, the aim of this work was to examine the effect of parameters viz. temperature, solvent to solid ratio, the concentration of the solvent, $\mathrm{pH}$ and extraction time on the extraction efficiency of phenolic compounds. Also, the intention was to examine the applicability of the unsteady diffusion model through the plant material and the empirical equation of Ponomaryov for modeling the solid-liquid extraction of total phenolics from barley. The data obtained were used to establish the kinetics and thermodynamics of the extraction process.

\section{Experimental \\ Plant materials \\ Barley sample was purchased at the local market in}

\footnotetext{
*Author address: Dušan Paunović, Department of Chemistry, Faculty of Sciences and Mathematics, University of Niš, Višegradska 33, 18000 Niš, Serbia

E-mail: dpaunovic3@gmail.com

The manuscript received: Jul, 24, 2014.

Paper accepted: October, 22, 2014.
} 
Serbia. Before being used, the plant material was comminuted by a hammer mill and sieved through a $<0.6 \mathrm{~mm}$ screen.

Chemicals and reagents

Gallic acid was purchased from Sigma Aldrich (Steineheim, Germany). Folin Ciocalteu's phenol reagent and sodium carbonate were purchased from Merck $\AA$ (KGaA, Darmstadt, Germany). Ethanol ( $96 \%$ by vol., HPLC grade) was from J.T. Baker.

Total polyphenolic content (TP)

The total polyphenolic content of the barley was measured spectrophotometrically at $760 \mathrm{~nm}$ after the reaction with Folin-Ciocalteu (FC) phenol reagent, according to the method described by Singleton et al. [10] and Stratil et al. [11]. The measurement was compared to a calibration line of the prepared gallic acid (GA) solution, and the results were expressed as milligrams of gallic acid equivalents (GAE) per gram (mg GAE/g). All measurements were performed in triplicate. The Agilent 8453 UVNis spectrophotometer was used for absorbance measurements and spectra recording, using an optical or quartz cuvettes of $1 \mathrm{~cm}$ optical path.

Initial contents of polyphenolic compounds in plant materials $\left(q_{0}\right)$

Macerated plant material $(2 \mathrm{~g})$ was weighed into a $250 \mathrm{~mL}$ Erlenmeyer flask with a ground stopper and covered with $100 \mathrm{~mL}$ of the extraction agent. The extraction was carried out by the maceration method for a period of 120 minutes. The extracts were separated from the residues by filtering through the Whatman No1 filter paper. The residues were extracted twice with the same fresh solvent and extracts combined. The combined extracts were concentrated and freed of solvent under reduced pressure at $45^{\circ} \mathrm{C}$, using a rotary evaporator (BUCHI Rotavapor R-200). The dried crude concentrated extracts were dissolved using the extraction solvent until used for the analyses. The dried extracts were prepared thrice and the results averaged. The value of the phenolics was determined spectrophotometrically. The value of the initial content of phenolic compounds in barley was $1.585 \mathrm{mg} \mathrm{GAE} / \mathrm{g}$.

The content of polyphenolic compounds in saturated liquid extracts (cmax)

Macerated plant material $(2 \mathrm{~g})$ was weighed into a $250 \mathrm{~mL}$ Erlenmeyer flask with a ground stopper and covered with $100 \mathrm{~mL}$ of the extraction agent. The extraction was carried out by the maceration method for a period of 120 minutes. The liquid extract was separated as before and used for extracting phenolic compounds from a further portion $(2 \mathrm{~g})$ of the fresh plant material. The extraction was repeated with the liquid extract and a further quantity of the fresh plant material $(2 \mathrm{~g})$. The extraction solvent was evaporated under a rotary evaporator at $45^{\circ} \mathrm{C}$. The dried crude concentrated extract was dissolved using the extraction solvent until used for the analyses. The content of total phenolic compounds was determined spectrophotometrically. The value of the content of phenolic compounds in saturated liquid extracts was 1.663 $\mathrm{mg} \mathrm{GAE} / \mathrm{g}$.

The extraction optimization for total polyphenolics Solvent/water ratio

Two grams of barley was extracted with $40 \mathrm{~mL}$ of aqueous ethanol. The evaluated ethanol concentrations were $20,30,50,70$ and $90 \%(v / v)$ in water for $120 \mathrm{~min}$ utes at room temperature. The other extraction conditions were as described above.

\section{$\mathrm{pH}$}

Two grams of barley was extracted with $40 \mathrm{~mL}$ of $30 \%$ ethanol with $0,0.1,1$ and $5 \% \mathrm{HCl}$ for 120 minutes at room temperature. The other extraction conditions were as described above.

\section{Solvent/raw material ratio}

Two grams of barley was extracted with $30 \%$ acidified aqueous ethanol $(5 \% \mathrm{HCl})$. The evaluated ethanol volumes were $30,40,50,60 \mathrm{~mL}$ for 120 minutes at room temperature. The other extraction conditions were described as previously.

The kinetics of extraction

Barley $(2 \mathrm{~g})$ and the extracting solvent $(60 \mathrm{~mL})$ were placed in a series of Erlenmeyer flasks $(250 \mathrm{~mL})$ and the flasks were macerated in 1, 5, 10, 15, 20, 40, 80 and 120 minutes. The temperature was controlled and maintained at $25 \pm 0.1^{\circ} \mathrm{C}$. After each time interval, a flask was taken out of the thermostatic bath and the liquid extract was separated from the plant residues by vacuum filtration. The content of phenolic compounds in the liquid extracts was determined spectrophotometrically. The procedure was repeated at $35 \pm 0.1^{\circ} \mathrm{C}$ and $45 \pm 0.1^{\circ} \mathrm{C}$.

The extraction optimization for total polyphenolics

The optimum conditions for the extraction of total polyphenolics were studied. Actually, there were many extraction factors affecting the extraction of total phenolics in plant samples including the extraction method, sample/solvent ratio, organic solvent/aqueous solvent ratio, $\mathrm{HCl}$ concentration and extraction time. The investigated parameters with their range for the extraction of total phenolics from the barley sample are summarized in Table 1.

Table 1. The investigated parameters with their range for the extraction of total phenolics from the barley sample

\begin{tabular}{cc}
\hline Parameter & Variation range \\
\hline Ethanol concentracion, $\%$ & $20,30,50,70,90$ \\
$\mathrm{HCl}$ concentracion, $\%$ & $0,0.1,1,5$ \\
Solvent/raw material ratio, V/m & $15,20,25,30$ \\
Extraction time, min & $1,5,10,20,40,80,120$ \\
Extraction method & maceration \\
\hline
\end{tabular}




\section{Results and discussion}

The extraction optimization and determination of total polyphenolics

To optimize the extraction conditions for total phenolic compounds, the extraction parameters, including solvent/sample ratio, ethanol/water ratio, $\mathrm{HCl}$ concentration and extraction time were investigated. The content of total phenolics as a function of the solvent concentration was evaluated. As ethanol is most frequently used in phenolics extraction, it was chosen as a solvent for the following step. As the results shown in Figure 1, the concentration of ethanol in the extraction medium had a significant effect on the extraction contents of the phenolic compounds. Based on the result of total phenolics, it was optimized at $30 \%$, and thus we suggested that most of the phenolic compounds present in barley samples had a moderately polar characteristic.

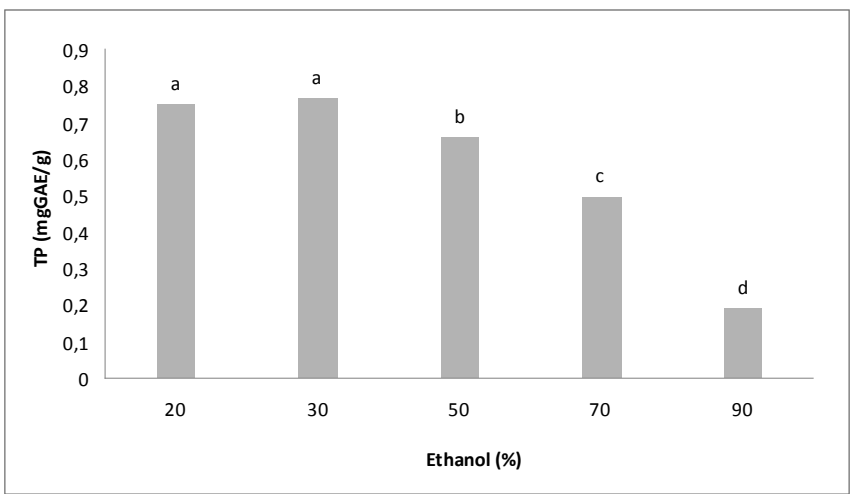

Figure 1. The effect of the extraction solvent on the extraction content of total phenolics from barley $(0 \% \mathrm{HCl} ; \mathrm{V} / \mathrm{m}=20)$. The values marked with different lower case letters $(a-d)$ are significantly $(p<0.05)$ different

The effect of acidified solvents on the extraction of barley phenolics was evaluated using different concentrations of $\mathrm{HCl}$ in $30 \%$ ethanol as the solvent. The suitably acidified conditions for the extraction of phenolic compounds were $5 \%(\mathrm{v} / \mathrm{v}) \mathrm{HCl}$ (Figure 2). The results showed that the content of phenolic compounds increased with increasing $\mathrm{HCl}$ concentrations.

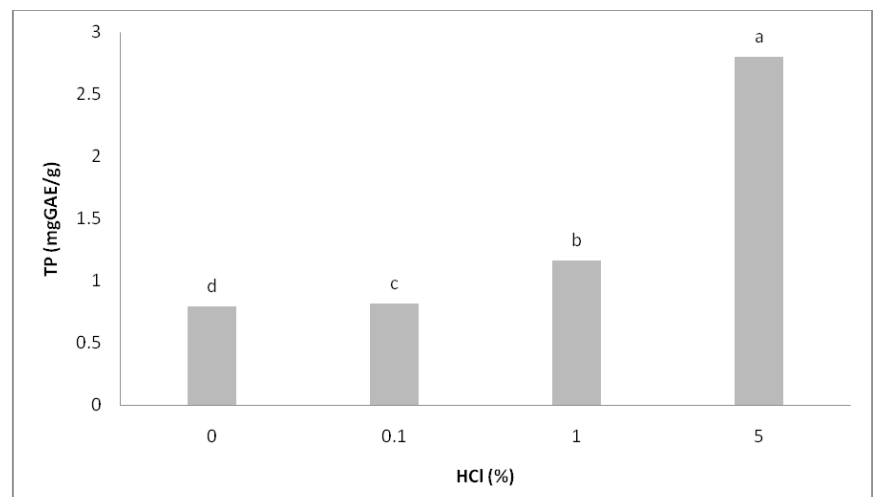

Figure 2. The effect of $\mathrm{HCl}$ concentration on the extraction content of total phenolics from barley ( $30 \%$ ethanol; $\mathrm{V} / \mathrm{m}=20)$. The values marked with different lower case letters $(a-d)$ are significantly $(p<0.05)$ different
In continuum, the solvent to raw material ratio was set at $15,20,25$ and 30 in order to investigate the influence of the solvent to raw material ratio on the content of total phenolic compounds (Figure 3). We could observe that, as the ratio of solvent to raw material was in the range of 15-30, the extraction phenolic compounds rapidly increased with the increasing ratio. Consequently, we concluded that high extraction phenolic compounds could be obtained with the 30 solvent to raw material ratio.

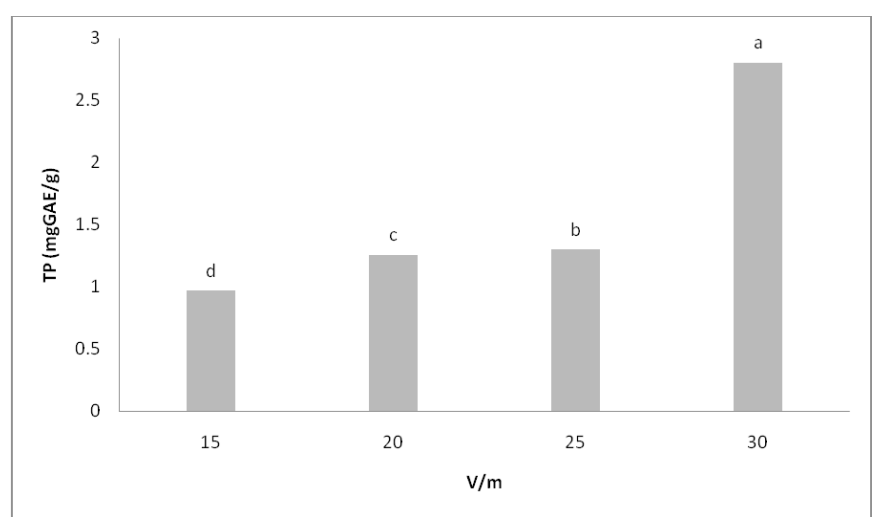

Figure 3. The effect of the solvent to raw material ratio on the extraction content of total phenolics from barley (30\% ethanol; $5 \% \mathrm{HCl}$ ). The values marked with different lower case letters $(a-d)$ are significantly $(p<0.05)$ different

The kinetics of the extraction

The kinetics of the extraction of total phenolic compounds from the barley was studied using $30 \%$ ethanol with $\%(\mathrm{v} / \mathrm{v}) \mathrm{HCl}$ at the solvent to raw material ratio of $30(\mathrm{v} / \mathrm{m})$ at 25,35 and $45^{\circ} \mathrm{C}$. The change of the contents of total phenolic compounds in the liquid extracts with the progress of the extraction is shown in Figure 4.

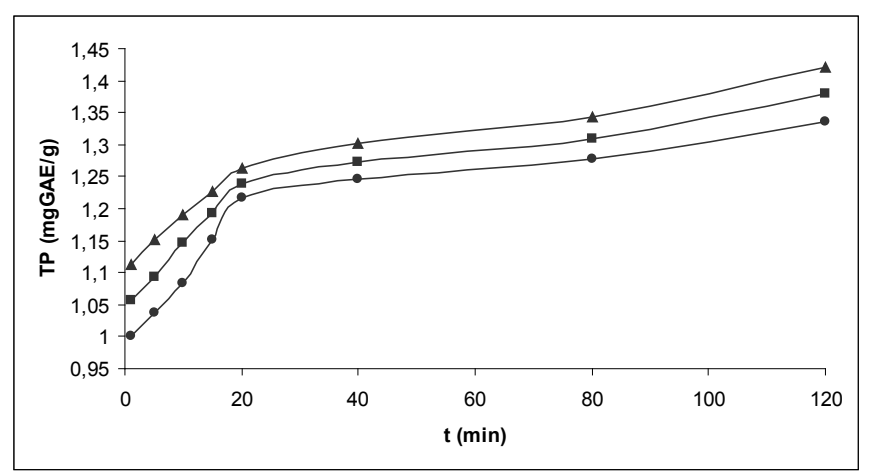

Figure 4. The variation of the content of phenolic compounds in liquid extracts with the increasing maceration time during the extraction at $(\bullet) 25 \pm 0.1{ }^{\circ} \mathrm{C} ;(\boldsymbol{\bullet}) 35 \pm 0.1{ }^{\circ} \mathrm{C}$ and $(\boldsymbol{\Delta}) 45 \pm 0.1$ ${ }^{\circ} \mathrm{C}(30 \%$ ethanol; $5 \% \mathrm{HCl} ; \mathrm{V} / \mathrm{m}=30)$

Two periods of the extraction can be observed for the extraction of phenolic compounds from barley: (a) a rapid increase in the content of phenolic compounds at the early beginning of the process known as washing and (b) a slow increase in the total phenolic contents with further progress of the extraction (approximately after the first 20 minutes) known as a slow extraction. 
Table 2. The kinetics equations of the solid-liquid extraction and their linearized forms

\begin{tabular}{ccc}
\hline Model & Kinetic equation & Linearized form \\
\hline Unsteady diffusion & $q_{i} / q_{0}=(1-b) e^{-k t}$ & $\ln \left(q_{i} / q_{0}\right)=\ln (1-b)-k t$ \\
Ponomaryov's empirical \\
equation
\end{tabular}

b-washing coefficient; k-slow extraction coefficient; qi-content of extractive substances in the plant material during the extraction; $\mathrm{q}_{0}$-content of extractive substances present in the plant material.

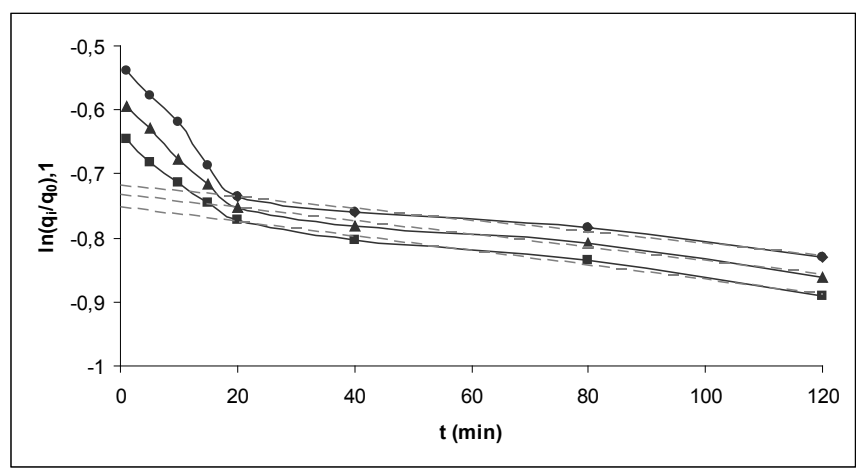

(a)

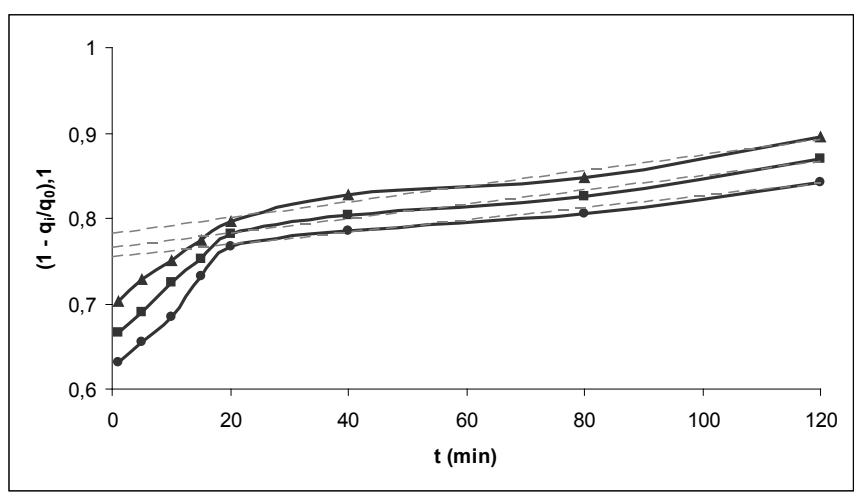

(b)

Figure 5. The linearized forms of kinetics equations: (a) the model based on unsteady diffusion through the plant material and (b) Ponomaryov's empirical equations at $(\bullet) 25 \pm 0.1{ }^{\circ} \mathrm{C}$; (घ) $35 \pm 0.1{ }^{\circ} \mathrm{C}$ and $(\mathbf{\Delta}) 45 \pm 0.1^{\circ} \mathrm{C}(30 \%$ ethanol; $5 \% \mathrm{HCl}$; V/ $\mathrm{m}=30$ )

The parameters of the kinetics models were calculated from the experimental data by means of the linear regression method using proper linearized forms of the kinetic equations, and are presented in Table 3 (the coefficient of linear correlation was higher than 0.92).

The model based on Ponomaryov's equation predicts the smallest values of the washing coefficient, while the model based on the unsteady diffusion through the plant material predicts the highest values of the coefficient.
Table 3. The values of kinetics parameters

\begin{tabular}{cccc}
\hline Model & Temperature, $\mathrm{K}$ & $\mathrm{b}$ & $\mathrm{k} \cdot 10^{-3}, \mathrm{~min}^{-1}$ \\
\hline \multirow{3}{*}{ Unsteady diffusion } & 298 & 0.810 & 0.95 \\
& 308 & 0.818 & 1.08 \\
& 318 & 0.824 & 1.18 \\
Ponomaryov's equation & 298 & & \\
& 308 & 0.754 & 0.76 \\
& 318 & 0.765 & 0.89 \\
& & 0.773 & 1.03 \\
\hline
\end{tabular}

The model based on Ponomaryov's equation predicts the smallest values of the washing coefficient, while the model based on the unsteady diffusion through the plant material predicts the highest values of the coefficient.

\section{Thermodynamics study}

The activation energy was calculated with the Arrhenius equation [12]:

$\mathrm{k}=\mathrm{A} \cdot \mathrm{e}^{-\mathrm{Ea} / \mathrm{RT}}$

where $k$ is the reaction rate (extraction) constant; $A$ is the Arrhenius constant or the frequency factor; $\mathrm{Ea}$ is the activation energy; $R$ is the universal gas constant and $T$ is the absolute temperature.

A plot of Ink vs 1 / T gives a straight line the slope of which represents the activation energy of the extraction - Ea / R, and the intercept of which is the Arrhenius constant, InA. The activation thermodynamic parameters were calculated according to the equations:

$\Delta H^{*}=\mathrm{Ea}-\mathrm{RT}$

$\Delta G^{*}=\Delta H^{*}-T \Delta S^{*}$

where $\Delta \mathrm{H}^{*}$ is the activation enthalpy; $\Delta \mathrm{S}^{*}$ is the activation entropy and $\Delta \mathrm{G}^{*}$ is the activation free energy or Gibb's energy. These activation thermodynamic parameters are shown in Table 4.

Table 4. The activation thermodynamic parameters for the phenolic compounds extraction with $30 \%$ ethanol at $25^{\circ} \mathrm{C}$

\begin{tabular}{ccccc}
\hline Model & $\mathrm{Ea}, \mathrm{kJmol}^{-1}$ & $\Delta \mathrm{H}^{*}, \mathrm{kJmol}^{-1}$ & $\Delta \mathrm{S}^{*}, \mathrm{JK}^{-1} \mathrm{~mol}^{-1}$ & $\Delta \mathrm{G}^{*}, \mathrm{kJmol}^{-1}$ \\
\hline $\begin{array}{c}\text { Unsteady } \\
\text { diffusion }\end{array}$ & 8.56 & 6.08 & -357.53 & 112.62 \\
$\begin{array}{c}\text { Ponomaryov's } \\
\text { equation }\end{array}$ & 11.97 & 9.48 & -350.45 & 113.83 \\
\hline
\end{tabular}

Meziane and Kadi (2008) determined $\mathrm{Ea}=8.56 \mathrm{kJmol}^{-1}$ for the oil extraction from olive cake. The Ea of the extraction of individual flavanols from green tea was in the range from 30 to $50 \mathrm{kJmol}^{-1}$ [13].

The thermodynamics consideration of the extraction process was necessary to conclude whether the process was spontaneous or not. Gibb's free energy $\left(\Delta \mathrm{G}^{0}\right)$, enthaIpy change $\left(\Delta \mathrm{H}^{0}\right)$ and entropy change $\left(\Delta \mathrm{S}^{0}\right)$ are calculated 
using the following equations:

$\mathrm{k}_{\mathrm{e}}=\mathrm{c}_{\mathrm{t}} / \mathrm{c}_{\max }$

$\Delta \mathrm{G}^{0}=-\mathrm{RT} \ln \mathrm{k}_{\mathrm{e}}$

$\mathrm{Ink}_{\mathrm{e}}=-\Delta \mathrm{H}^{0} / \mathrm{RT}+\Delta \mathrm{S}^{0} / \mathrm{R}$

where $c_{t}$ is the contents of total phenolics in the liquid extract at temperature $\mathrm{T} ; \mathrm{C}_{\max }$ is the contents of phenolics in the saturated liquid extract, $\Delta \mathrm{H}^{0}$ is the enthalpy change; $\Delta S^{0}$ is the entropy change and $\Delta \mathrm{G}^{0}$ is Gibb's free energy [14].

Equation (6) is Van't Hoff reaction and plot of Ink $\mathrm{k}_{\mathrm{e}}$ vs $1 / T$ was used to find the values of $\Delta H^{0}$ from the slope. The values of $\mathrm{k}_{\mathrm{e}}, \Delta \mathrm{G}^{0}, \Delta \mathrm{H}^{0}$ and $\Delta \mathrm{S}^{0}$ for the extraction of phenolic compounds using $30 \%$ ethanol were calculated using equations (4)-(6), and are given in Table 5.

Table 5. Thermodynamics parameters

\begin{tabular}{ccccc}
\hline Temperature, $\mathrm{K}$ & $\mathrm{K}_{\mathrm{e}}$ & $\Delta \mathrm{G}^{0}, \mathrm{kJmol}^{-1}$ & $\Delta \mathrm{H}^{0}, \mathrm{kJmol}^{-1}$ & $\Delta \mathrm{S}^{0}, \mathrm{JK}^{-1} \mathrm{~mol}^{-1}$ \\
\hline 298 & 80.39 & -10.86 & 2.36 & 44.39 \\
308 & 82.92 & -11.31 & & \\
318 & 85.39 & -11.76 & & \\
\hline
\end{tabular}

The negative value for Gibb's free energy for the phenolic compounds extraction from barley showed that the process was feasible and spontaneous and that the extraction increased with increasing the temperature as $\Delta \mathrm{G}^{0}$ became more negative. The value of $\Delta \mathrm{H}^{0}$ was positive, indicating that the extraction was endothermic and that the process was irreversible. The results are similar to that of Topallar and Gecgel [15] and Saxena et al. [14].

\section{Conclusion}

The experimental results showed that the conditions during the extraction process had a significant influence on the extractability of total phenolic compounds from barley. The highest efficiency of the total phenolic compounds extraction at the temperature of $45^{\circ} \mathrm{C}$ and 120 minutes of the extraction was achieved with the $30 \%$ aqueous ethanol solution in the presence of $5 \% \mathrm{HCl}$.

Two empirical kinetics models of solid-liquid extraction were evaluated using the experimental data. Modeling of the extraction kinetics will contribute not only to fundamental understanding of the process, but also to its better control and optimization. The results indicated that the extraction process was endothermic, irreversible and spontaneous.

\section{Acknowledgement}

This research was supported by grant number 172047 from the Serbian Ministry of Science and Environmental Protection. The authors are grateful for the financial support provided by this Ministry.

\section{References}

[1] H. Zhao, W. Fan, J. Dong, J. Lu, J. Chen, L. Shan, Y. Lin, W. Kong, Evaluation of antioxidant activities and total phenolic contents of typical malting barley varieties, Food Chemistry, 107(1) (2008) 296-304.

[2] W. Friedrich, A. Eberhardt, R. Golensa, Investigation of proanthocyanidins by HPLC with electrospray ionization mass spectometry, European Food Research and Technology, 211(1) (2000) 56-64.

[3] M. Bonoli, V. Verardo, E. Marconi, M.F. Caboni, Antioxidant phenols in barley (Hordeum vulgare L.) flour: comparative spectrophotometric study among extraction method of free and bound phenolic compounds, Journal of Agricultural and Food Chemistry, 52(16) (2004) 51955200.

[4] A. Papetti, M. Daglia, C. Aceti, M. Quaglia, C. Gregotti, G. Gozzani, Isolation of an in vitro and ex vivo antiradical melanoidin from roasted barley, Journal of Agricultural and Food Chemistry, 54(4) (2006) 1209-1216.

[5] P. Arnnok, C. Ruangviriyachai, R. Mahachai, S. Techawongstien, S. Chanthai, Determination of total phenolic and anthocyanin contents in the pericarp of hot chilli pepper (Capsicum Annuum L.), International Food Research Journal, 19(1) (2012) 235-243.

[6] Y.Y. Thoo, S.K. Ho, J.Y. Liang, C.W. Ho, C.P. Tan, Effects of binary solvent extraction system, extraction time and extraction temperature on phenolic antioxidants and antioxidant capacity from mengkudu (Morinda citrifolia), Food Chemistry, 120(1) (2010) 290-295.

[7] K.K Chew, M.Z. Khoo, S.Y. Ng, Y.Y. Thoo, W.M. Wan Aida, C.W. Ho, Effect of ethanol concentration, extraction time and extraction temperature on the recovery of phenolic compounds and antioxidant capacity of Orthosiphon stamineus extracts, International Food Research Journal, 18(4) (2011) 1427-1435.

[8] S. Jokić, D. Velić, M. Bilić, A. Bucić-Kojić, M. Planinić, S. Tomas, Modelling of the process of solid-liquid extraction of total polyphenols from soybeans, Czech Journal of Food Sciences, 28 (2012) 206-212.

[9] S. Kitanović, D. Milenović, V.B. Veljković, Empirical kinetics models for the resinoid extraction from aerial parts of St. John's wort (Hypericum perforatum L.), Biochemical Engineering Journal, 41 (2008) 1-11.

[10] V.L. Singleton, R. Orthofer, R.M. Lamuela-Raventos, Analysis of total phenols and other oxidation substrates and antioxidants by means of Folin-Ciocalteu reagent, Methods in Enzymology, 299 (1999) 152-178.

[11] P. Stratil, B. Klejdus, V. Kuban, Determination of total content of phenolic compounds and their antioxidant activity in vegetables - evaluation of spectrophotometric methods, Journal of Agricultural and Food Chemistry, 54(3) (2006) 607-616.

[12] S. Meziane, H. Kadi, Kinetics and thermodynamics of oil extraction from olive cake, Journal of the American Oil Chemists' Society, 85(4) (2008) 391-396.

[13] W.E. Price, J.C. Spitzer, The kinetics of extraction of individual flavanols and caffeine from a Japanese green tea (Sen Cha Uji Tsuyu) as a function of temperature, Food Chemistry, 50(1) (1994) 19-23.

[14] D.K. Saxena, S.K. Sharma, S.S. Sambi, Kinetics and thermodynamics of gossypol extraction from defatted cottonseed meal by ethanol, Polish Journal of Chemical Technology, 14(2) (2012) 29-34. 
[15] H. Topallar, U. Gecgel, Kinetics and thermodynamics of oil extraction from sunflower seeds in the presence of aqueous acidic hexane solutions, Turkish Journal of Chemistry, 24 (2000) 247-253.

Izvod

\section{KINETIKA I TERMODINAMIKA PROCESA ČVRSTO-TEČNE EKSTRAKCIJE UKUPNIH POLIFENOLA IZ JEČMA}

Dušan Đ. Paunović, Snežana S. Mitić, Danijela A. Kostić, Milan N. Mitić, Branka T. Stojanović, Jovana Lj. Pavlović

Departman za hemiju, Prirodno-matematički fakultet, Univerzitet u Nišu, Niš, Srbija

Ispitivan je uticaj koncentracije rastvarača, $\mathrm{pH}$, temperature, solvo modula i vremena na ekstrakciju ukupnih fenola iz ječma. Najefikasniji rastvarač (30\% vodeni rastvor etanola sa $5 \% \mathrm{HCl}$ v/v), pri solvo modulu od $30 \mathrm{~mL} / \mathrm{g}$ (odnos zapremine rastvarača i sirovog materijala), je korišćen za modelovanje čvrsto-tečne ekstrakcije ukupnih fenola. Sadržaj ukupnih fenola u ekstraktu ječma je određen spektrofotometrijski, korišćenjem Folin-Ciocalteu metode na 760 nm. Sadržaj fenolnih jedinjenja zavisi od ekstrakcionih uslova koji se primenjuju. Mehanizam ekstrakcije se odvija u sledećim koracima: prvo, rastvaranje fenolnih jedinjenja u blizini površine čestica (ispiranje) i drugo, difuzija iz čvrste materije u tečni rastvarač (spora ekstrakcija). Proces je opisan matematički korišćenjem modela zasnovanog na nestacionarnoj difuziji i Ponomarjeve empirijske jednačine. Dobijeni podaci se koriste za uspostavljanje kinetike i termodinamike procesa ekstrakcije.
Ključne reči: čvrsto-tečna ekstrakcija, ječam, ukupni polifenoli, kinetika, termodinamički parametri 